\title{
Front Matter: Volume 11854
}

, "Front Matter: Volume 11854," Proc. SPIE 11854, International Conference on Extreme Ultraviolet Lithography 2021, 1185401 (22 October 2021); doi: $10.1117 / 12.2617273$

SPIE. Event: SPIE Photomask Technology + EUV Lithography, 2021, Online Only 


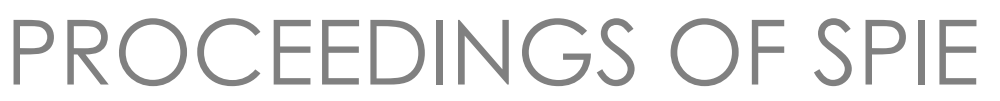

\title{
International Conference on Extreme Ultraviolet Lithography 2021
}

\author{
Kurt G. Ronse \\ Patrick P. Naulleau \\ Paolo A. Gargini \\ Toshiro Itani \\ Eric Hendrickx \\ Editors
}

27 September - 1 October 2021

Online Only, United States

Sponsored and Published by

SPIE 
The papers in this volume were part of the technical conference cited on the cover and title page. Papers were selected and subject to review by the editors and conference program committee. Some conference presentations may not be available for publication. Additional papers and presentation recordings may be available online in the SPIE Digital Library at SPIEDigitalLibrary.org.

The papers reflect the work and thoughts of the authors and are published herein as submitted. The publisher is not responsible for the validity of the information or for any outcomes resulting from reliance thereon.

Please use the following format to cite material from these proceedings:

Author(s), "Title of Paper," in International Conference on Extreme Ultraviolet Lithography 2021, edited by Kurt G. Ronse, Patrick P. Naulleau, Paolo A. Gargini, Toshiro Itani, Eric HendrickX, Proc. of SPIE 11854, Seven-digit Article CID Number (DD/MM/YYYY); (DOI URL).

ISSN: 0277-786X

ISSN: 1996-756X (electronic)

ISBN: 9781510645523

ISBN: 9781510645530 (electronic)

Published by

SPIE

P.O. Box 10, Bellingham, Washington 98227-0010 USA

Telephone +1 3606763290 (Pacific Time)

SPIE.org

Copyright (C) 2021 Society of Photo-Optical Instrumentation Engineers (SPIE).

Copying of material in this book for internal or personal use, or for the internal or personal use of specific clients, beyond the fair use provisions granted by the U.S. Copyright Law is authorized by SPIE subject to payment of fees. To obtain permission to use and share articles in this volume, visit Copyright Clearance Center at copyright.com. Other copying for republication, resale, advertising or promotion, or any form of systematic or multiple reproduction of any material in this book is prohibited except with permission in writing from the publisher.

Printed in the United States of America by Curran Associates, Inc., under license from SPIE.

Publication of record for individual papers is online in the SPIE Digital Library.

\section{SP|E. DIGITAL}

Paper Numbering: A unique citation identifier (CID) number is assigned to each article in the Proceedings of SPIE at the time of publication. Utilization of CIDs allows articles to be fully citable as soon as they are published online, and connects the same identifier to all online and print versions of the publication. SPIE uses a seven-digit CID article numbering system structured as follows:

- The first five digits correspond to the SPIE volume number.

- The last two digits indicate publication order within the volume using a Base 36 numbering system employing both numerals and letters. These two-number sets start with 00, 01, 02, 03, 04, 05, 06, 07, 08, 09, 0A, OB ... 0Z, followed by 10-1Z, 20-2Z, etc. The CID Number appears on each page of the manuscript. 


\section{Contents}

EUV SCANNER AND IMAGING I

1185405 Simulation of polychromatic effects in high NA EUV lithography (Invited Paper) [1 1854-20]

$1185406 \quad$ Impact of mask corner rounding on pitch $40 \mathrm{~nm}$ contact hole variability [1 1854-48]

EUV PROCESS AND MATERIALS I

1185409 Development of fluoro-free surfactant rinse solutions for EUV photoresists [1 1854-54]

EUV PATTERNING SOLUTIONS I

11854 OA Towards high NA patterning readiness: materials, processes and etch transfer for P24 Line Space [1 1854-47]

11854 OC 28nm-pitch Ru interconnects patterned with a 0.33NA-EUV single exposure [1 1854-22]

11854 OD Analysis of advanced technology nodes and h-NA EUV introduction: a cost perspective [1 1854-8]

EUV SCANNER AND IMAGING II

$11854 \mathrm{OH} \quad$ Pupil optimization for after etch defectivity: what imaging metrics matter? (Invited Paper) [1 1854-33]

$11854 \mathrm{Ol} \quad$ Contribution of mask roughness in stochasticity of high-NA EUV imaging [1 1854-50]

EUV LIGHT SOURCE

11854 OK Update of $>300 \mathrm{~W}$ high power LPP-EUV source challenge IV for semiconductor HVM [1 1854-5] 
11854 OS Small scale, big impact: the world's thinnest and strongest free-standing carbon nanotube membrane [11854-3]

11854 OT Exploration of alternative mask for 0.33NA EUV single patterning at pitch 28nm [1 1854-2]

\section{EUV PATTERNING SOLUTIONS II}

11854 OY Deep learning-based defect detection using large FOV SEM for 28 nm pitch BEOL layer patterned with 0.33NA single exposure EUV [1 1854-27]

$11854 \mathrm{OZ} \quad$ Printability and propagation of stochastic defects through a study of defects programmed on EUV mask [1 1854-52]

$1185410 \quad$ High NA EUV: a challenge for metrology, an opportunity for atomic force microscopy [1 1854-43]

$1185411 \quad$ Unsupervised machine learning based SEM image denoising for robust contour detection [1 1854-25]

\section{NEW EUV MASK TECHNOLOGY II}

1185412 Optimizations aspects for EUV low-k1 logic with the low-n mask (Invited Paper) [1 1854-38]

1185414 First results of EUV-scanner compatibility tests performed on novel 'high-NA' reticle absorber materials [1 1854-19]

1185415 Comparison of deposition techniques for Mo/Si reflective multilayers for EUV mask blanks [1 1854-34]

1185416 Classification of EUV masks based on the ratio of the complex refractive index $k /(1-n)$ [1 1854-49]

\section{POSTER SESSION I}

1185418 iN5 EUV single expose patterning evaluation for via layers [1 1854-23]

1185419 Design and realization of an in-lab EUV dual beamline for industrial and scientific applications [11854-21]

11854 1B New metrology technique for measuring wafer geometry on a full 300mm silicon wafer [1 1854-57]

iv 
Proc. of SPIE Vol. 11854 1185401-5 Downloaded From: https://www.spiedigitallibrary.org/conference-proceedings-of-spie on 26 Apr 2023
Terms of Use: https://www.spiedigitallibrary.org/terms-of-use 